\title{
FINITE ELEMENT ANALYSIS OF JACKETED REINFORCED CONCRETE COLUMN SUBJECTED TO UNI-AXIAL LOAD
}

\author{
Anushree $^{1}$, Vijay kumar $\mathbf{Y ~ M}^{2}$ \\ ${ }^{1}$ structural Engineering, Adichunchanagiri institute of technology, Chikmagalur, Karnataka, India \\ ${ }^{2}$ structural Engineering, Adichunchanagiri institute of technology, Chikmagalur, Karnataka, India
}

\begin{abstract}
One strategy for the jacketing of reinforced concrete column is to target the improvement of local vulnerabilities in columns related to inadequate strength (compressive \& Flexural) or poor ductility. Theoretical analysis have been carried out in the present study for different column sections of jacket thickness of $50 \mathrm{~mm}, 75 \mathrm{~mm}$ and $100 \mathrm{~mm}$ for jacketed RC columns subjected to uni-axial compressive loading. The uni-axial load carrying capacity along the major axes have been carried out under balanced section condition. Linear static finite element analysis has been carried out for the jacketed RC columns to compare the confined concrete strength (fcc) of finite element analysis with that of theoretical analysis, to plot the variation of stresses at the central core concrete and at the interface of old and new concrete. The displacements at core with respect to both major and minor axis are also plotted. Considerations have been given for variations in the properties of different types concretes used in the jacket and the original column. In order to find out the increase in the confined capacity of jacketed columns due to strengthening with respect to original column, theoretical analysis has been carried out.
\end{abstract}

Keywords: Uni-axial load, NISA Display IV, Jacketing, confined compressive strength.

\section{INTRODUCTION}

Reinforced concrete is concrete in which reinforcement bars ("rebars"), reinforcement grids, plates or fibers have been incorporated to strengthen the concrete in tension. . Concrete is strong in compression, but weak in tension, thus adding reinforcement increases the strength in tension. In addition, the failure strain of concrete in tension is so low that the reinforcement has to hold the cracked sections together. . A reinforced concrete section where the concrete resists the compression and steel resists the tension can be made into almost any shape and size for the construction industry.

Reinforced concrete (RC) columns are critical elements, whose failure can cause the collapse of a structure. Therefore, their repairing and strengthening are frequent in order to guarantee or increase their ultimate load. Rehabilitation and strengthening of reinforced concrete structures is a dynamically growing division of structural engineering. In recent years an increased application of new repair and strengthening systems of reinforced concrete load-carrying structures has been noted. The problem of strengthening the reinforced concrete structures appeared for the first time when their proper function was modified or they were used in a different manner than previously planned.

Strengthening of the reinforced concrete structures is one of the most difficult and important tasks of civil engineering. Individual approach to the problem is a necessity since any ready-made solution can be applied. One of the prime objectives is to provide detailed technical and cost-effective analyses. Structures must be carefully examined in order to determine their technical condition, to find reasons for deterioration and strengthening as well as to establish service requirements of the reinforced structures. It is also essential to analyze their technical design, dig out open pits and carry out suitable measurements. Cost-effectiveness of each of the proposed strengthening techniques should be considered and compared to the cost of a new structure. The strengthening methods applied should ensure the required safety margin and guarantee a sufficient reliability over time.

Some of the most widely used methods for repair / strengthening of RC columns include:

1. Jacketing of part or the entire member:

2. Heat tensioning of full thin steel plates or tie plates

3. Glueing of thin steel sheets on damaged members by using epoxy resin laid onto the steel sheets and concrete surfaces

4. Tying of the damaged parts of the column using steel ties

5. Mild steel fixed round the damaged element

6. Wrapping a column with a high strength fiber composite (HSFC) jacket

The main purposes of jacketing are:

1. To increase concrete confinement by transverse reinforcement, especially for circular cross sectional columns. 
2. To increase flexural strength by longitudinal reinforcement provided they are well anchored at critical sections.

3. To increase shear strength by transverse reinforcement.

4. To Increase the local capacity of structural elements.

7. Reduction of the seismic demand by means of supplementary damping.

The model is taken as confined model [1][3] and it is tied using the lateral ties [2]. The behavior of analytical model ie load capacity under un-axial eccentric loading is calculated as per [5][7]. The FEM analysis is done to check the stresses and displacement [6].

\section{METHODOLOGY}

To study the variation of stresses at the central core concrete, at the interface of old and new concrete and at the column surface and lateral displacement along the length of the column, first theoretically calculate the axial compression and uni-axial moment and convert it to the pressure and apply that load on the FEM model and execute it. Then plot the variation of stresses and displacement. Then also compare the increases in the confined capacity of jacketed columns with respect to the original column.

\section{THEORETICAL ANALYSIS OF JACKETED RC UNI-AXIALLY LOADED COLUMNS}

The theoretical analysis of jacketed RC column subjected to uni-axial loading has been done. The grade of the original column concrete considered is $20 \mathrm{MPa}$ and that of jacket concrete are $30 \mathrm{MPa}$ and $40 \mathrm{MPa}$. Details of the sections considered and reinforcement provided are given in the tables 1 and 2 respectively. Stirrup spacing has been calculated as per IS456-2000.

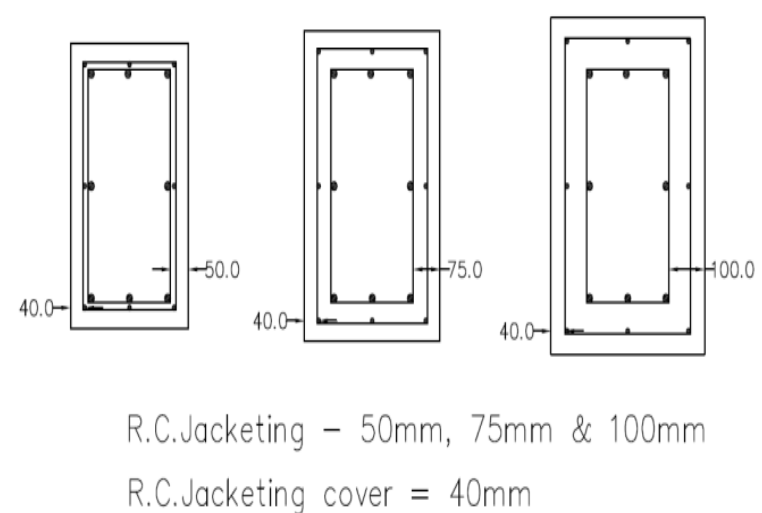

Fig $\mathbf{- 1}$ shows the general column section with different jacketing thickness and cover
Table-1: Reinforcement details of original and jacketed column have same spacing for original column and jacketed column

\begin{tabular}{|l|l|l|l|l|}
\hline $\begin{array}{l}\text { Original } \\
\text { column } \\
\text { dimension } \\
(\mathrm{mm})\end{array}$ & \multicolumn{2}{|l|}{ Jacketed column dimension } & $\begin{array}{l}\text { Stirrup } \\
\text { For } \\
\text { j0mm } \\
\text { jacketing }\end{array}$ & $\begin{array}{l}\text { For } \\
75 \mathrm{~mm} \\
\text { jacketing }\end{array}$ \\
\hline $230 \times 450$ & $330 \times 550$ & $\begin{array}{l}\text { For 100mm } \\
\text { jacketing }\end{array}$ & \\
\hline $300 \times 300$ & $400 \times 400$ & $450 \times 450$ & $500 \times 500$ & 300 \\
\hline $300 \times 450$ & $400 \times 550$ & $450 \times 600$ & $500 \times 650$ & 250 \\
\hline $300 \times 600$ & $400 \times 700$ & $450 \times 750$ & $500 \times 800$ & 300 \\
\hline
\end{tabular}

Table-2: Reinforcement details of original and jacketed column have same spacing for original column and jacketed column

\begin{tabular}{|c|c|c|c|c|c|}
\hline \multirow{2}{*}{$\begin{array}{l}\text { Original } \\
\text { Column } \\
\text { Size }\end{array}$} & \multicolumn{4}{|c|}{ Longitudinal steel provided } & \multirow{2}{*}{$\begin{array}{l}\text { spacing } \\
\text { Original } \\
\text { Column }\end{array}$} \\
\hline & $\begin{array}{l}\text { Original } \\
\text { Column }\end{array}$ & 50 & 75 & 100 & \\
\hline $230 \times 450$ & $4 \# 20+4 \# 16$ & $10 \# 10$ & $4 \# 20$ & $6 \# 20$ & 200 \\
\hline $300 \times 300$ & $4 \# 20+4 \# 16$ & $8 \# 10$ & $4 \# 20$ & $8 \# 16$ & 300 \\
\hline $300 \times 450$ & $4 \# 25+4 \# 16$ & $10 \# 10$ & $8 \# 16$ & $6 \# 20$ & 250 \\
\hline $300 \times 600$ & $8 \# 25$ & $10 \# 10$ & $6 \# 20$ & $8 \# 20$ & 300 \\
\hline
\end{tabular}

3.1 Theoretical Original To Jacketed $P_{u}$ And $M_{u}$ Comparison

Analysis of the strength of a given column section basically implies determination of its design strength component $P_{u}$ and $M_{u}$ with the objective of assessing the safety of the column section subjected to specified factored load. The design strength of an eccentrically loaded column depends on the eccentricity of loading. For uni-axial eccentricity (e), the design strength has two components: an axial compression component $\left(\mathrm{P}_{\mathrm{u}}\right)$ and a corresponding uni-axial moment component $\left(\mathrm{M}_{\mathrm{u}}\right)$. The $\mathrm{P}_{\mathrm{u}}$ and $\mathrm{M}_{\mathrm{u}}$ has been calculated for an original column of different column section for a concrete strength of $20 \mathrm{MPa}$ for a jacketed column of different $f_{\text {co }}$ of jacketed thickness $50 \mathrm{~mm}, 75 \mathrm{~mm}$ and $100 \mathrm{~mm}$. The obtained $P_{u}$ and $\mathrm{M}_{\mathrm{u}}$ of original column is compared with a jacketed column and is listed in the below table- $3 \& 4$. 
Table-3: Comparison of axial compression component of original and jacketed column

\begin{tabular}{|c|c|c|c|c|c|c|c|}
\hline \multirow{3}{*}{$\begin{array}{l}\text { Original } \\
\text { column } \\
\text { dimension }\end{array}$} & \multirow[b]{2}{*}{$\begin{array}{l}\text { Original } \\
\text { Column } \\
\mathrm{f}_{\mathrm{ci}}=20 \mathrm{MPa}\end{array}$} & \multicolumn{2}{|c|}{$50 \mathrm{~mm}$ jacketed column } & \multicolumn{2}{|c|}{$75 \mathrm{~mm}$ jacketed column } & \multicolumn{2}{|c|}{$100 \mathrm{~mm}$ jacketed column } \\
\hline & & $\begin{array}{l}\mathrm{f}_{\mathrm{ci}}=20 \\
\mathrm{f}_{\mathrm{co}}=30 \\
(\mathrm{MPa})\end{array}$ & $\begin{array}{l}\mathrm{f}_{\mathrm{ci}}=20 \\
\mathrm{f}_{\mathrm{co}}=40 \\
(\mathrm{MPa})\end{array}$ & $\begin{array}{l}\mathrm{f}_{\mathrm{ci}}=20 \\
\mathrm{f}_{\mathrm{co}}=30 \\
(\mathrm{MPa})\end{array}$ & $\begin{array}{l}\mathrm{f}_{\mathrm{ci}}=20 \\
\mathrm{f}_{\mathrm{co}}=40 \\
(\mathrm{MPa})\end{array}$ & $\begin{array}{l}\mathrm{f}_{\mathrm{ci}}=20 \\
\mathrm{f}_{\mathrm{co}}=30 \\
(\mathrm{MPa})\end{array}$ & $\begin{array}{l}\mathrm{f}_{\mathrm{ci}}=20 \\
\mathrm{f}_{\mathrm{co}}=40 \\
(\mathrm{MPa})\end{array}$ \\
\hline & $\mathrm{P}_{\mathrm{u}}(\mathrm{kN})$ & $\mathrm{P}_{\mathrm{u}}(\mathrm{kN})$ & $\mathrm{P}_{\mathrm{u}}(\mathrm{kN})$ & $\mathrm{P}_{\mathrm{u}}(\mathrm{kN})$ & $\mathrm{P}_{\mathrm{u}}(\mathrm{kN})$ & $\mathrm{P}_{\mathrm{u}}(\mathrm{kN})$ & $\mathrm{P}_{\mathrm{u}}(\mathrm{kN})$ \\
\hline $230 \times 450$ & 251.23 & 611.82 & 749.27 & 836.19 & 1039.96 & 1092.48 & 1380 \\
\hline $300 \times 300$ & 123.44 & 477.71 & 592.12 & 764.661 & 946.82 & 850.58 & 1112.11 \\
\hline $300 \times 450$ & 334.33 & 733.71 & 873.22 & 891.56 & 1110.82 & 1251.18 & 1565.88 \\
\hline $300 \times 600$ & 445.01 & 922.6 & 1088.17 & 1199.74 & 1469.72 & 1479.4 & 1841.87 \\
\hline
\end{tabular}

Table-4: Comparison of Uni-axial moment component of original and jacketed column

\begin{tabular}{|c|c|c|c|c|c|c|c|}
\hline \multirow{3}{*}{$\begin{array}{l}\text { Original } \\
\text { column } \\
\text { dimension }\end{array}$} & \multirow[b]{2}{*}{$\begin{array}{l}\text { Original } \\
\text { Column } \\
\mathrm{f}_{\mathrm{ci}}=20 \mathrm{MPa}\end{array}$} & \multicolumn{2}{|c|}{ 50mm jacketed column } & \multicolumn{2}{|c|}{ 75mm jacketed column } & \multicolumn{2}{|c|}{$100 \mathrm{~mm}$ jacketed column } \\
\hline & & $\begin{array}{l}\mathrm{f}_{\mathrm{ci}}=20 \\
\mathrm{f}_{\mathrm{co}}=30 \\
(\mathrm{MPa})\end{array}$ & $\begin{array}{l}\mathrm{f}_{\mathrm{ci}}=20 \\
\mathrm{f}_{\mathrm{co}}=40 \\
(\mathrm{MPa})\end{array}$ & $\begin{array}{l}\mathrm{f}_{\mathrm{ci}}=20 \\
\mathrm{f}_{\mathrm{co}}=30 \\
(\mathrm{MPa})\end{array}$ & $\begin{array}{l}\mathrm{f}_{\mathrm{ci}}=20 \\
\mathrm{f}_{\mathrm{co}}=40 \\
(\mathrm{MPa})\end{array}$ & $\begin{array}{l}\mathrm{f}_{\mathrm{ci}}=20 \\
\mathrm{f}_{\mathrm{co}}=30 \\
(\mathrm{MPa})\end{array}$ & $\begin{array}{l}\mathrm{f}_{\mathrm{ci}}=20 \\
\mathrm{f}_{\mathrm{co}}=40 \\
(\mathrm{MPa})\end{array}$ \\
\hline & $\mathrm{M}_{\mathrm{u}}(\mathrm{kN}-\mathrm{m})$ & $\mathrm{M}_{\mathrm{u}}(\mathrm{kN}-\mathrm{m})$ & $\mathrm{M}_{\mathrm{u}}(\mathrm{kN}-\mathrm{m})$ & $\mathrm{M}_{\mathrm{u}}(\mathrm{kN}-\mathrm{m})$ & $\mathrm{M}_{\mathrm{u}}(\mathrm{kN}-\mathrm{m})$ & $\mathrm{M}_{\mathrm{u}}(\mathrm{kN}-\mathrm{m})$ & $\mathrm{M}_{\mathrm{u}}(\mathrm{kN}-\mathrm{m})$ \\
\hline $230 \times 450$ & 147.85 & 287.97 & 309.9 & 386.28 & 439.98 & 484 & 542.8 \\
\hline $300 \times 300$ & 68.83 & 160.81 & 175.63 & 280.82 & 307.25 & 297.17 & 338.97 \\
\hline $300 \times 450$ & 202.67 & 289.64 & 314 & 476.39 & 517.81 & 436.16 & 500.63 \\
\hline $300 \times 600$ & 365.34 & 550.1 & 586.47 & 730.87 & 792.1 & 835.43 & 1011.34 \\
\hline
\end{tabular}

\section{DESCRIPTION OF GEOMETRICAL AND} MATERIAL PROPERTIES USED

The accuracy of the structural analysis using numerical methods depends on the representation of the behavior of material under different state of stresses and loading conditions. The details of the properties employed for finite element modeling are given in table

Table-5: Geometrical and material properties

\begin{tabular}{|c|c|}
\hline $\begin{array}{l}\text { Original column dimensions } \\
\qquad(\mathrm{mm})\end{array}$ & $\begin{array}{c}230 \times 450,300 \times 300,300 \times 450, \\
300 \times 600\end{array}$ \\
\hline Column height $(\mathrm{m})$ & 3 \\
\hline Jacket thickness (mm) & 50,75 and 100 \\
\hline \multicolumn{2}{|c|}{ Original column concrete and Jacketing concrete } \\
\hline Modulus of Elasticity(MPa) & 22360,27386 and 31623 \\
\hline Poisson's ratio & 0.15 \\
\hline \multicolumn{2}{|c|}{ Longitudinal Reinforcement and Stirrups } \\
\hline Modulus of Elasticity(MPa) & 200000 \\
\hline Poisson's ratio & 0.3 \\
\hline
\end{tabular}

\section{FINITE ELEMENT ANALYSIS}

The columns are modeled as one end free and other end hinged. In this study axial load along with uni-axial moment has been applied on the column by converting it as equivalent pressure. The details of the material properties and loads are tabulated in the table. Modeling of RC jacketed using NISA software is has shown in figure 2 and plan view of normal stress distribution in jacketed RC column at free end (top), at center and at bottom is has shown in figure 5 to 7 . 


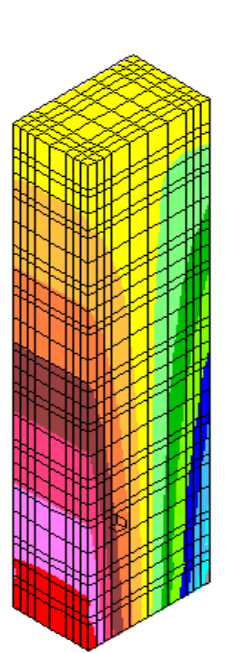

SZZ - STRESSES

VIEN -20.12182
RANGE 12.02961

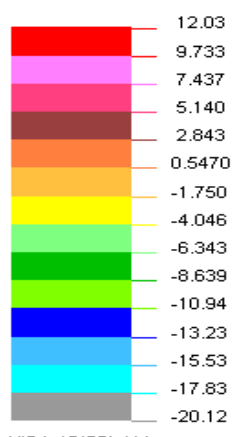

NISA / DISPLAY AUG/6/2012 54649
Fig-3 :Isometric view of normal stress distribution in the jacketed RC column
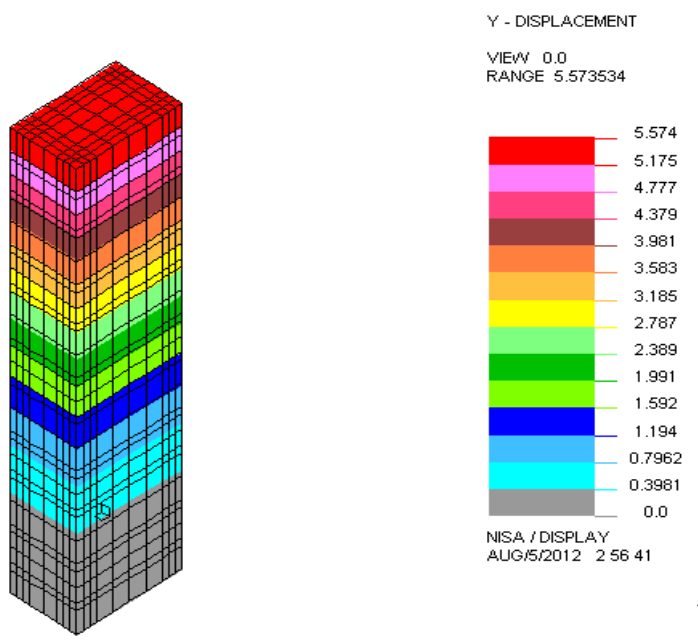

NISA / DISPLAY

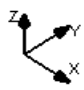

Fig-4 :Isometric view of displacement( $\mathrm{Y}$ - axis) in the jacketed RC column
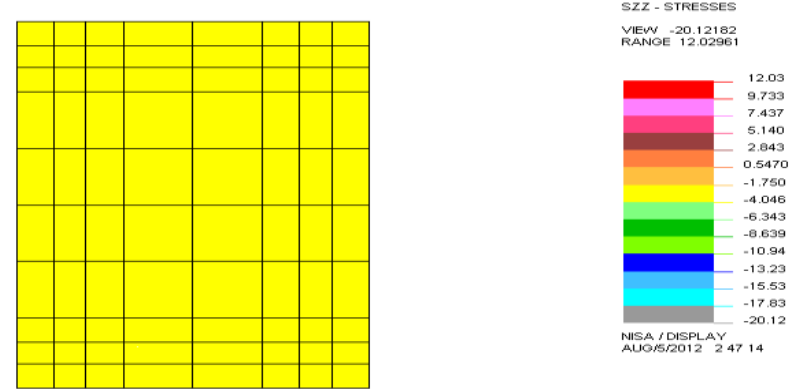

Fig-5 :plan view of normal stress distribution in the jacketed $\mathrm{RC}$ column( at free end)
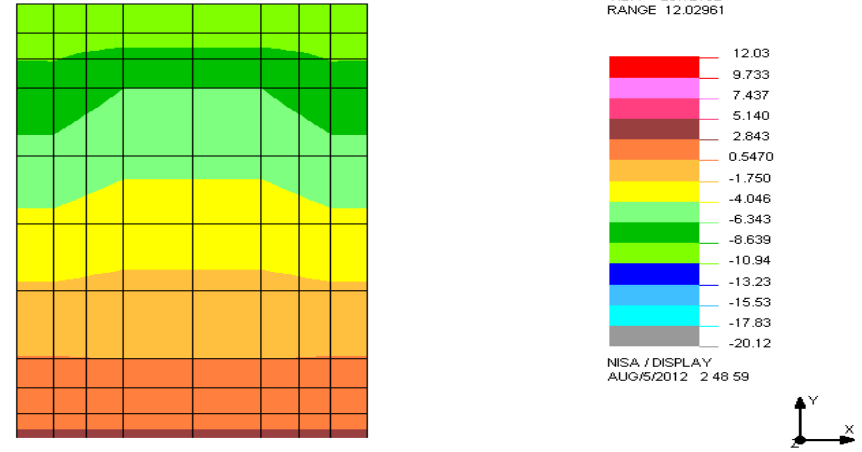

Fig-6 :plan view of normal stress distribution in the jacketed $\mathrm{RC}$ column( at centre)

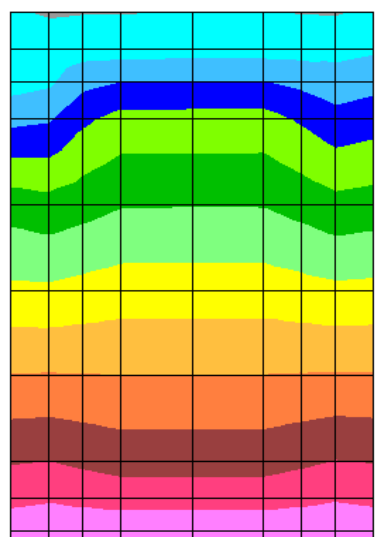

SZZ - STRESSES VIEW -20.12182
RANGE 12.02961
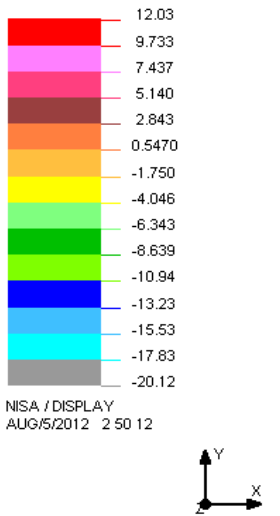

Fig-7 :plan view of normal stress distribution in the jacketed $\mathrm{RC}$ column( at bottom)

\section{RESULTS AND DISCUSSION}

Table-6: comparison of theoretical and finite element results

\begin{tabular}{|l|c|c|c|}
\hline Columns & Theoretical & Theoretical & Stirrup \\
& $\mathrm{f}_{\mathrm{ci}}=20$ & $\mathrm{f}_{\mathrm{ci}}=20$ & spacing \\
& $\mathrm{f}_{\mathrm{co}}=30$ & $\mathrm{f}_{\mathrm{co}}=40$ & \\
\hline $230 \times 450$ & 31.2 & 21.8 & 200 \\
\hline $300 \times 300$ & 29.24 & 22.69 & 300 \\
\hline $300 \times 450$ & 28.74 & 22.11 & 250 \\
\hline $300 \times 600$ & 30.51 & 23.97 & 300 \\
\hline
\end{tabular}


Table-7: Comparison of confined concrete strength of theoretical \& finite element analysis with columns having same spacing of inner and outer stirrups in longitudinal direction

\begin{tabular}{|c|c|c|c|c|}
\hline $\begin{array}{c}\text { Column } \\
\text { section }\end{array}$ & $\begin{array}{c}\text { Theoretical } \\
\mathrm{f}_{\mathrm{ci}}=20 \mathrm{MPa} \\
\mathrm{f}_{\mathrm{co}}=30 \mathrm{MPa}\end{array}$ & $\begin{array}{c}\text { FEM } \\
\mathrm{f}_{\mathrm{ci}}=20 \mathrm{MPa} \\
\mathrm{f}_{\mathrm{co}}=30 \mathrm{MPa}\end{array}$ & $\begin{array}{c}\text { Theoretical } \\
\mathrm{f}_{\mathrm{ci}}=20 \mathrm{MPa} \\
\mathrm{f}_{\mathrm{co}}=40 \mathrm{MPa}\end{array}$ & $\begin{array}{c}\text { FEM } \\
\mathrm{f}_{\mathrm{ci}}=20 \mathrm{MPa} \\
\mathrm{f}_{\mathrm{co}}=40 \mathrm{Mpa}\end{array}$ \\
\hline $230 \times 450$ & 31.20 & 19.48 & 23.80 & 23.27 \\
\hline $300 \times 300$ & 29.24 & 15.24 & 22.69 & 18.69 \\
\hline $300 \times 450$ & 31.74 & 19.31 & 24.11 & 22.89 \\
\hline $300 \times 600$ & 31.51 & 18.41 & 23.97 & 21.92 \\
\hline
\end{tabular}

Due to confinement of core concrete by both inner and outer sets of stirrups, its original strength gets increased. In order to validate the theoretical results, the same has been compared with that of the finite element analysis results. The theoretical and finite element results obtained for the different column sections and three different jacket thicknesses are as shown in the tables 6and 7, has been taken up for the comparison. The theoretical results obtained from the analysis of jacketed column of different thickness and varying concrete strength have been considered. It can be observed from the table 6 and 7 that the results of theoretical and finite element analysis are approximately matching with some percentage of errors.

\section{VARIATION OF THE NORMAL STRESSES IN \\ JACKETED RC COLUMNS}

In order to know the behaviour of jacketed RC columns under the applied pressure in NISA the normal stress SZZ has been extracted at the points as shown in the figure 3.9. The stress at the point 1 and 5 is at the new concrete, stress at point 2 and 4 is at the interface of the old and new concrete and stress at point 3 is at core center (x-axis).

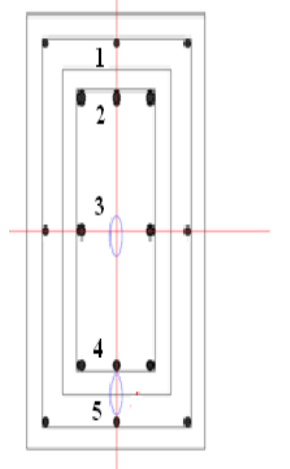

$$
\begin{aligned}
& 1=\text { Normal stress szz at the new concrete } \\
& 2=\text { Normal stress szz at the interface between old and new concrete } \\
& 3=\text { Normal stress szz at the cor e center } \\
& 4=\text { Normal stress szz at the interface between old and new concrete } \\
& 5=\text { Normal stress szz at the new concrete }
\end{aligned}
$$

Fig- 8: $\mathrm{C} / \mathrm{S}$ of jacketed column

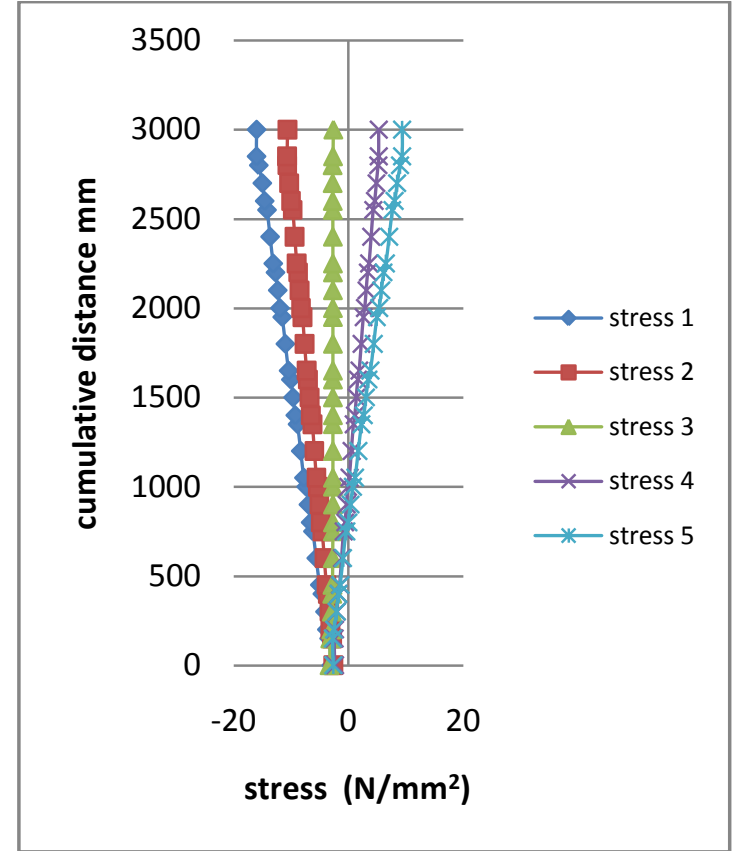

(a) $\mathrm{f}_{\mathrm{ci}}=20 \mathrm{MPa}$ and $\mathrm{f}_{\mathrm{co}}=30 \mathrm{MPa}$

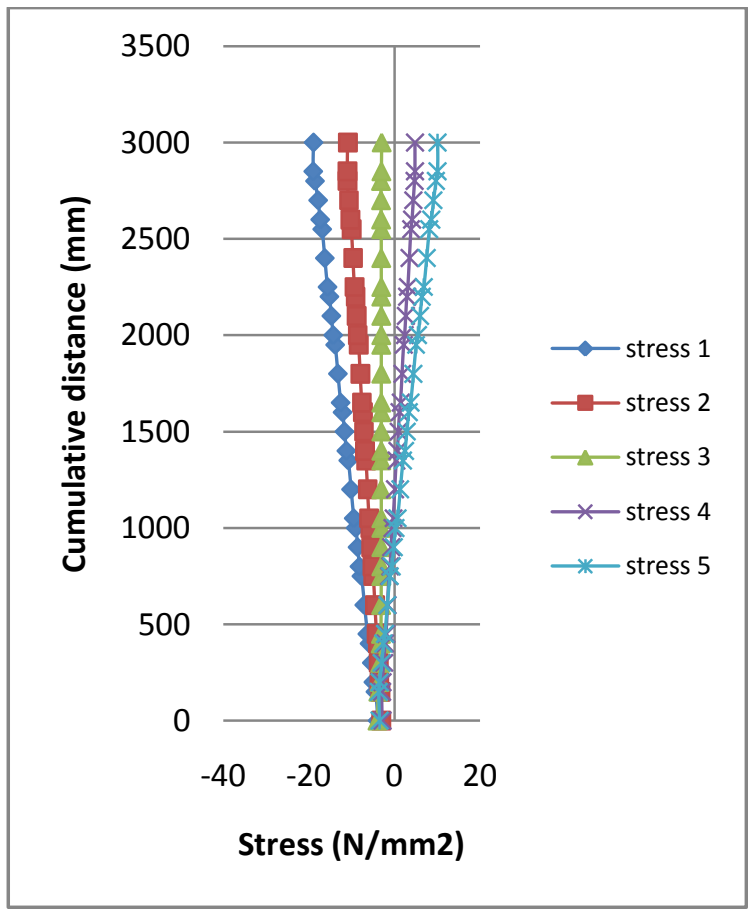

(b) $\mathrm{f}_{\mathrm{ci}}=20 \mathrm{MPa}$ and $\mathrm{f}_{\mathrm{co}}=40 \mathrm{MPa}$

Chart -1: shows the variation of normal stressess in the central core of column,interface of the jacket \& original column and at the new concrete along the direction parallel to applied load for $(230 \times 450) \mathrm{mm}$ column section, with $50 \mathrm{~mm}$ thick jacket. 


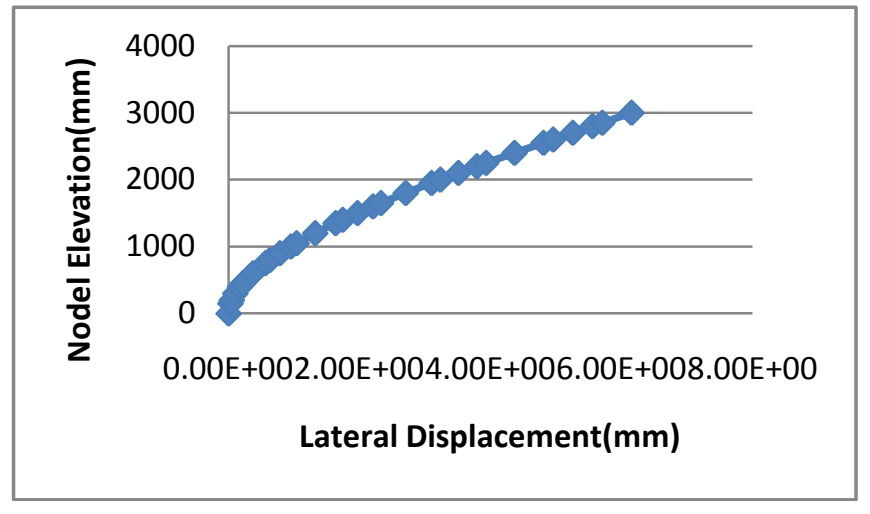

(a) $\mathrm{f}_{\mathrm{ci}}=20 \mathrm{MPa}$ and $\mathrm{f}_{\mathrm{co}}=30 \mathrm{Mpa}$

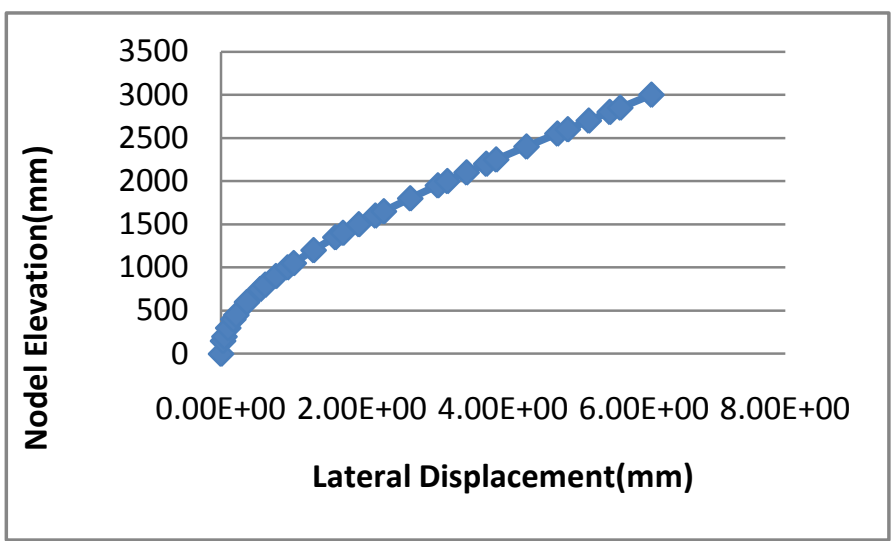

(b) $\quad \mathrm{f}_{\mathrm{ci}}=20 \mathrm{Mpa}$ and $\mathrm{f}_{\mathrm{co}}=40 \mathrm{Mpa}$

Chart- 2: The lateral displacment along a longitudinal axis of the column for column section $(230 \mathrm{~mm} \times 450 \mathrm{~mm})$, having $\mathrm{RC}$ jacket thicknesses $50 \mathrm{~mm}$.

\section{CONCLUSIONS}

The present work is concerned with the theoretical study of jacketed and original columns and also finite element analysis carried out for jacketed RC columns with a commercially available finite element analysis package NISA/DISPLAY-IV. Based on the theoretical and finite element analysis study carried out, the following conclusions have been drawn.

1. Varying the stirrups of outer jackets the load carrying capacity of column will increase when stirrups spacing are kept little closer compare to inner stirrups of column in vertical direction.

2. It can be visualized that the higher the grade of concrete used for RC columns increases its strength.

3. Uni-axial load carrying capacity of original columns increases by introducing a jacketing layer of varying thickness. Also, it can be observed that the jacket thickness increases the load carrying capacity of jacketed columns.

4. The load carrying capacity increases with increasing the size of original column and with increasing grade of structural concrete strength in the jacket and with the thickness of the jacket.

5. The thickness of the jacket that should be provided depends on grade of structural concrete strength in the original column and jacket ie., if higher grade of concrete is used the thickness of the jacket is less and vice-versa.

6. The uni-axial load carrying capacity of the confined columns improves, because the compressive strength of the confined concrete enhances by the confinement effect.

7. The jacket concrete should be at least 25 to $30 \%$ stronger than the original column concrete strength.

\section{REFERENCES}

[1] Shamim A. Sheikh "A comparative study of confinement models", ACI Journal, July - august 1982, PP.296-603.

[2] Shamim A. Sheikh and C.C. Yeh, "Flexural Behavior of Confined Concrete Columns". ACI Journal, May June 1986, PP.389-404.

[3] Sheikh S A and Uzumeri,S.M., "Analytical model for concrete confinement in tied columns". Journal of the Structural Division. ASCE, 108(12)( 1982), 2703-2722.

[4] Mohamed El Sayed and Tamer El Maaddawy, "Analytical model for prediction of load capacity of RC columns confined with CFRP under uniaxial and biaxial eccentric loading" Materials and Structures, 44(2011)299-311.

[5] J. B. Mander, M. J. N. Priestley, and R. Park: stressstrain model for concrete subjected to uniaxial compressive loading and confined by transverse reinforcement. ASCE, Journal of structural Engineering, Vol.114, No. 8, August, 1988.

[6] Minho Kwon, Enrico Spacone "Three-dimensional finite element analyses of reinforced concrete columns, Computers and Structures Vol.80,August2002, PP.199-212.

[7] Reinforced Concrete Design, 2nd Edition, by S.Unnikrishna Pillai and Devdas Menon, Tata McGraw-Hill Publishing Company Limited, New Delhi, 2003.

[8] Limit State Design of Reinforced Concrete, 2nd Edition, by P.C.Varghese, Prentice-Hall of India Pvt. Ltd., New Delhi, 2002.

[9] Indian standard Code of practice for plain and reinforced concrete (fourth revision), IS 456-2000, Bureau of Indian standard, July 2000, New Delhi. 